\title{
A NEW FERRY ACROSS THE MISSOURI RIVER
}

The subscribers have obtained from the General Assembly of the State of Iowa, a charter to keep a Ferry across the Missouri River at Council Bluffs, and a permit from the Indian Agent at Council Bluffs Agency, to land in the Indian Territory, are prepared with new and safe boats and tried watermen, to attend faithfully to the duties of said Ferry. For those going to Oregon or Califoruia, this is decidedly the best crossing place. Aside from being over three hundred miles nearer than by Independence, it saves the difficult and dangerous crossings of the two forks of Kansas River, the Platt River and several others, and ensures the protection of the U. S. Troops as well as the Agency of the Ottoes, Omahas and Pawnees being at the Bluffs.

The roads to this Ferry from the various crossings on the Mississippi through the interior of Iowa are good, well supplied with wood and water, and every other article needed by the emigrant, and at $\mathbf{S t}$. Francis and Council Bluffs, all articles of food, furniture, \&c., that will be needed in crossing the mountain, can be had on reasonable terms, as well as good and experienced guides and mountaineers; in fact it is designed to be prepared with all such articles as the traveler may need to add to his comfort and safety.

Those who wish to spend the winter here in order to cross the mountains early, can find abundance of all they require for themselves and teams. This Ferry being on the direct line from Chicago to the South Pass, gives it a decided advantage over the old route. All North of the Iowa should pass through Iowa City, via Trading House, 25 miles, (Bob Hutchinson's residence) Snook's Grove, 24 miles; Newton, 34 miles; this is the county seat of Jasper county; to Ft. Desmoine (Raccoon Forks), 30 miles; here goods and stores of every kind can be had on fair terms.-From this place the road is the best of any in the State. To Brown's ford on North river, 18 miles; Happy grove, 6 miles, to Marvin's grove, 6 miles; to Tucker's grove 10 miles ( $1 / 2$ mile off the road) to Allen's 9 miles, at the bridge across Middle river; to east fork of the Nodaway, 13 miles, good ford; to west fork of the Nodaway, Campbell's grove, 15 miles, stream bridged-plenty of timber; to east fork of the Nisabotony, 12 miles. Ferrin's Ferry at the old Indian village. Here the northern road intersects the Mormon trail; to Mount Scott, 17 miles to west fork, 5 miles; to Silver Creek, 10 miles; to Keg creek, 6 miles; here the road forks, the right hand leads to Kanesville, the principal Mormon town, the left to St. Francis opposite Council Blufis Agency in Nebraska Territory. 
Copyright of Annals of Iowa is the property of State of Iowa, by \& through the State Historical Society of Iowa and its content may not be copied or emailed to multiple sites or posted to a listserv without the copyright holder's express written permission. However, users may print, download, or email articles for individual use. 